\title{
Faktor Keamanan Stabilitas Lereng pada Kondisi Eksisting dan Setelah Diperkuat Dinding Penahan Tanah Tipe Counterfort dengan Program Plaxis
}

\author{
Rizki Ramadhan', Munirwansyah ${ }^{2}$, Munira Sungkar ${ }^{3}$ \\ ${ }^{1}$ Mahasiswa Magister Teknik Sipil, Fakultas Teknik, Universitas Syiah Kuala- \\ Jl. Tgk. Syeh Abdul Rauf No. 7, Darussalam Banda Aceh 23111, \\ ${ }^{2}$ Dosen Magister Teknik Sipil, Fakultas Teknik, Universitas Syiah Kuala- \\ J1. Tgk. Syeh Abdul Rauf No. 7, Darussalam Banda Aceh 23111, \\ e-mail : rizkiramadhan0459@gmail.com. No. HP : 085260653899
}

\begin{abstract}
ABSTRAK
Ruas jalan batas Aceh Tengah/Gayo Lues-Blangkejeren (N.022) Km 438+775 merupakan salah satu ruas jalan Nasional Lintas Tengah Provinsi Aceh, yang sering mengalami tanah longsor karena berada di daerah perbukitan. Longsoran yang terjadi pada lokasi tersebut disebabkan oleh gerusan air limpasan permukaan jalan, kurang optimalnya drainase dan tidak adanya outlet untuk pembuangan air serta lapisan tanah di bawah perkerasan aspal terdiri dari material lepas. Oleh karena itu, diperlukan kajian perkuatan lereng dengan dinding penahan tanah tipe Counterfort. Kajian ini bertujuan untuk menganalisis stabilitas lereng dengan mendapatkan angka faktor keamanan dan mengidentifikasi pola keruntuhan lereng. Analisis dilakukan untuk mendapatkan faktor keamanan dan pola keruntuhan lereng yaitu dengan menggunakan program Plaxis 2D dan metode irisan. Perhitungan faktor keamanan untuk dinding penahan tanah tipe Counterfort dilakukan secara manual. Adapun parameter tanah input yang digunakan adalah berat volume kering $\left(\gamma_{d}\right)$, berat volume basah $\left(\gamma_{\mathrm{w}}\right)$, permeabilitas $(\mathrm{k})$, modulus young $\left(E_{\text {ref }}\right)$, paisson's rasio $(\nu)$, sudut geser $(\phi)$, kohesi $(\mathrm{c})$. Hasil analisis stabilitas lereng pada kondisi eksisting menggunakan program Plaxis dan metode irisan dengan jari-jari (r) 65,06 meter didapatkan faktor keamanan sebesar 1,038 dan 1,079 dengan kondisi lereng tidak aman (FK < 1,25). Hasil analisis setelah diperkuat dinding penahan tanah tipe counterfort dan minipile dengan panjang 12 meter didapatkan angka faktor keamanan 1,268 dengan kondisi lereng tidak aman (FK < 1,5). Dengan demikian, maka diperlukan perkuatan tambahan dengan menggunakan angkur pada counterfort. Hasil analisis stabilitas lereng setelah diperkuat dinding penahan tanah tipe counterfort, minipile dan angkur dengan panjang 20 meter serta sudut kemiringan $30^{\circ}$ didapatkan angka faktor keamanan 1,513 dengan kondisi lereng aman (SF > 1,5).
\end{abstract}

Kata kunci : longsoran; counterfort, plaxis 2D; faktor keamanan.

\begin{abstract}
The Aceh Tengah / Gayo Lues-Blangkejeren road segment (N.022) Km $438+775$ is one of the Central Cross National Roads in the Province of Aceh, which often experiences landslides due to being in billy areas. Landslides that occur in these locations are caused by scouring of road runoff, lack of optimal drainage and the absence of outlets for drainage and soil layers under asphalt pavement consisting of loose material. Therefore, a slope reinforcement study with Counterfort type retaining wall is needed. This study aims to analyze slope stability by obtaining safety factor numbers and identifying slope failure patterns. Analysis was carried out to obtain safety factors and slope failure patterns by using 2D Plaxis and slice methods. The calculation of safety factors for Counterfort type retaining walls is done manually. The imput soil parameters used are dry volume weight ( $\gamma d)$, wet volume weight ( $(w)$ ), permeability (k), modulus young (Eref), paisson's ratio (v), shear angle ( $\phi)$, cohesion (c). The results of slope stability analysis on the existing conditions using the Plaxis program and the slice method with radius (r) 65.06 meters found that safety factors were 1.038 and 1.079 with unsafe slope conditions (FK <1.25). The results of the analysis after reinforced counterfort and minipile type retaining wall with a length of 12 meters found 1,268 safety factor numbers with unsafe slope conditions (FK <1,5). Thus,
\end{abstract}


additional reinforcement is needed by using anchor on the counterfort. The results of slope stability analysis after reinforced counterfort, minipile and anchor type retaining walls with a length of 20 meters and a slope of $30^{\circ}$ were obtained with a safety factor number of 1.513 with safe slope conditions (SF> 1.5).

Keywords : landslide, counterfort, plaxis 2D, safety factor.

\section{PENDAHULUAN}

Longsoran pada ruas jalan batas Aceh Tengah/Gayo Lues-Blangkejeren (N.022) $\mathrm{Km} 438+775$ disebabkan oleh gerusan air limpasan permukaan jalan (run off) yang diakibatkan tidak dikendalikan dengan baik dan kurang optimalnya drainase dan tidak adanya outlet untuk pembuangan air. Pembangunan saluran drainase sebagai pengendalian air pada lokasi tersebut terputus pada ujung kaki bukit yang mengakibatkan pembuangan air dalam saluran langsung ke tubuh lereng. Hal tersebut dapat menyebabkan volume tanah bertambah dan kondisi lereng dalam keadaan jenuh. Adapun penyebab lainnya adalah lapisan tanah di bawah perkerasan aspal terdiri dari material granular (lepas). Dalam hal ini, daya ikat (kohesi) tanah yang lemah sehingga butiran-butiran tanah dapat terlepas dari ikatannya dan bergeser (shear) ke bawah dengan menyeret butiran lain yang ada disekitarnya membentuk massa yang lebih besar. Lemahnya kuat geser (shear strength) tanah dapat disebabkan oleh kandungan air (moisture content) dan kelolosan air (permeabilitas) tanah maupun potensi bidang geser yang terbentuk dari longsoran massa tanah tersebut.

Adapun tujuan dari penelitian ini adalah untuk menganalisis faktor keamanan (safety factor) terhadap stabilitas lereng pada kondisi eksisting (natural condition) dengan metode irisan (ordinary method) dan program Plaxis 2D serta menganalisis faktor keamanan setelah diperkuat konstruksi dinding penahan tanah tipe Counterfort hanya menggunakan program saja. Untuk perhitungan faktor keamanan (safety factor) terhadap stabilitas konstruksi dinding penahan tanah tipe Counterfort dilakukan secara manual.

\subsection{Stabilitas lereng}

Lereng adalah penampakan alam yang disebabkan karena adanya beda tinggi di dua tempat [1]. Permukaan tanah yang tidak horizontal, komponen gravitasi cenderung untuk menggerakkan tanah ke bawah [2]. Jika komponen gravitasi sedemikian besar sehingga berlawanan terhadap geseran yang dapat dikembangkan oleh tanah pada bidang longsornya terlampaui, maka akan terjadi longsoran.

\subsection{Konsep Faktor Keamanan Lereng}

Pada umumnya nilai faktor keamanan FK $\geq 1,25$ adalah desain normal untuk memberikan perkiraan faktor keamanan dalam analisis stabilitas lereng [3]. Hal ini penting untuk meyakinkan bahwa desain lereng aman dan untuk mencegah faktor yang tidak terduga selama analisis dan konstruksi seperti data yang salah, kesalahan analisis, kecakapan kerja dan pengawasan di lapangan yang kurang.

Parameter yang dihasilkan dalam analisis stabilitas lereng adalah bentuk bidang keruntuhan dan faktor keamanan [4]. Faktor keamanan digunakan untuk mengidentifikasi stabilitas lereng yang didefinisikan sebagai perbandingan antara kuat geser tanah dan tegangan geser yang bekerja pada massa tanah, seperti terlihat pada Persamaan 1. 


$$
F K=\frac{\text { KuatGeser }}{\text { TeganganGerer }}
$$

Besar faktor keamanan sangat tergantung pada kualitas hasil penyelidikan tanah dan pengalaman perencana. Semakin rendah kualitas penyelidikan tanah dan pengalaman perencana, semakin besar faktor keamanan [5].

Faktor keamanan berdasarkan studistudi tentang keruntuhan lereng menunjukan bahwa Safety factor $<1,25$ adalah keruntuhan lereng bisa terjadi [6]. Sedangkan faktor keamanan untuk desain menunjukan bahwa safety factor $>1,5$ aman untuk perkuatan lereng [7].

Perhitungan stabilitas lereng sebelum dilakukan penanganan didapatkan angka keamanan dengan metode Fellenius $0,95085<1,5$ (tidak aman), sedangkan program Plaxis $0,9522<1,5$ (tidak aman). Setelah dilakukan penanganan didapatkan angka keamanan dengan metode Fellenius $1,744>1,5$ (aman), sedangkan program Plaxis 1,7413>1,5 [8].

Perhitungan stabilitas lereng yang diperkuat dinding penahan tanah tipe kantilever dengan dimensi ukuran tinggi 5 meter, lebar atas 0.3 meter, lebar tapak 2.5 meter dan tinggi tapak 0.5 meter menggunakan program Plaxis didapatkan nilai faktor keamanan yaitu sebesar 1,654 > 1,25 [9].

\subsection{Metode Irisan}

Metode irisan secara umum
digunakan untuk membagi
kelongsoran ke dalam beberapa irisan
vertikal. Lebar dari tiap-tiap irisan tidak
harus sama [10].


Kabupaten Aceh Tamiang dan Provinsi Sumatera Utara.

\subsection{Pengambilan Sampel}

Pengambilan sampel tanah dilakukan dengan menggunakan metode Hand Bore. Metode Hand Bore adalah penyelidikan tanah dengan cara menggali tanah menggunakan band bor dengan kedalaman yang telah direncanakan, kemudian dilaksanakan pengambilan sampel menggunakan Tube. Jumlah sampel yang diambil berjumlah 3 titik pada masingmasing kedalaman berdasarkan data sekunder yaitu bor log dan SPT. Sampel yang diambil terdiri dari sampel tanah terganggu (disturbed sample) dan tanah yang tidak terganggu (undistrubed sample) pada ruas jalan batas Aceh Tengah/Gayo LuesBlangkejeren (N.022) Km 438+775.

\subsection{Parameter Tanah}

Parameter tanah ini merupakan data yang digunakan untuk memperoleh hasil perhitungan analisis kestabilan lereng. Data yang digunakan untuk analisis stabilitas lereng dengan menggunakan program Plaxis 2D adalah berat volume tanah ( $\gamma$ ), kohesi (c), dan sudut geser $(\phi)$ yang diperoleh dari hasil pengujian sampel tanah pada ruas Jalan batas Aceh Tengah/Gayo LuesBlangkejeren (N.022) Km 438+775 di laboratorium. Sedangkan untuk Poisson ratio (u), modulus Young $\left(\mathrm{E}_{\mathrm{ref}}\right)$ dan koefisien permeabilitas tanah (k) diperoleh dari hasil interpretasi sesuai jenis tanah yang didiskripsikan setelah pengujian.

Tabel 1 : Parameter Input Pada Program Plaxis

\begin{tabular}{lcccc}
\hline \multirow{2}{*}{ Parameter Tanah } & \multicolumn{3}{c}{ Km 438+775 } & \multirow{2}{*}{ Satuan } \\
\cline { 2 - 4 } & Lapisan 1 & Lapisan 2 & Lapisan 3 & \\
\hline Material model & MC & MC & MC & - \\
Type of behaviour & Drained & Undrained & Undrained & - \\
Dry soil weight $\left(\gamma_{\text {dry }}\right)$ & 10,693 & 12,001 & 14,486 & $\mathrm{kN} / \mathrm{m}^{3}$ \\
Wet soil weight $\left(\gamma_{\text {wet }}\right)$ & 15,206 & 16,514 & 20,928 & $\mathrm{kN} / \mathrm{m}^{3}$ \\
Horizontal permeability $\left(\mathrm{k}_{\mathrm{x}}\right)$ & 0,01 & 0,001 & 0,001 & $\mathrm{~m} / \mathrm{day}$ \\
Vertical permeability $\left(\mathrm{k}_{\mathrm{y}}\right)$ & 0,01 & 0,001 & 0,001 & $\mathrm{~m} / \mathrm{day}$ \\
Young's modulus $\left(\mathrm{E}_{\text {ref }}\right)$ & 78480 & 29430 & 19620 & $\mathrm{kN} / \mathrm{m}^{2}$ \\
Poisson's ratio $(\mathrm{v})$ & 0,3 & 0,3 & 0,35 & - \\
Cohession $(\mathrm{c})$ & 45,093 & 35,774 & 33,648 & $\mathrm{kN} / \mathrm{m}^{2}$ \\
Friction angle $(\phi)$ & 20,415 & 26,967 & 25,700 & $\circ$ \\
Dilatancy angle $(\Psi)$ & - & - & - & $\circ$ \\
\hline
\end{tabular}

\subsection{Perhitungan Stabilitas Lereng dengan Metode Irisan (Ordinary Method)}

Perhitungan stabilitas lereng dengan metode irisan (ordinary method), terlebih dahulu dilakukan analisis stabilitas lereng menggunakan program Plaxis 2D untuk mendapatkan pola keruntuhan dan faktor keamanan. Metode irisan (ordinary method) dilakukan dengan cara membagi bidang longsor ke beberapa irisan agar lebih mudah dilakukan analisis terhadap faktor keamanan lereng. Adapun langkah-langkah 
perhitungan dengan metode irisan (ordinary method) adalah sebagai berikut:

1. Menentukan bidang lengkung kelongsoran dengan dibantu program Autocad untuk mendapat besarnya jarijari $\mathrm{R}$ dan titik pusat lingkaran (P).

2. Membagikan bidang longsor ke beberapa irisan agar memudahkan perhitungan luas bidang longsor secara akurat.

3. Menentukan sudut bidang longsor pada tiap-tiap irisan.

4. Melakukan perhitungan luas tiap-tiap irisan menggunakan persamaan luas berdasarkan bentuk-bentuk irisan.

5. Melakukan perhitungan berat irisan $\operatorname{tanah}(\mathrm{W})$.

6. Melakukan perhitungan faktor keamanan lereng dengan menggunakan persamaan 2 .

\subsection{Pengolahan Data}

Analisis kestabilan lereng dengan menggunakan program Plaxis 2D membutuhkan pemodelan lereng yang sesuai dengan data yang ada sehingga diperoleh hasil yang akurat. Adapun analisis program Plaxis 2D memiliki tiga tahapan, yaitu:

1. Tahapan masukan data.

2. Tahapan kalkulasi, dan

3. Tahapan keluaran data.

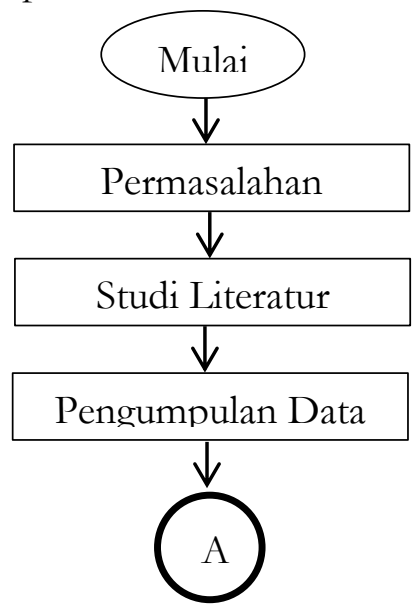

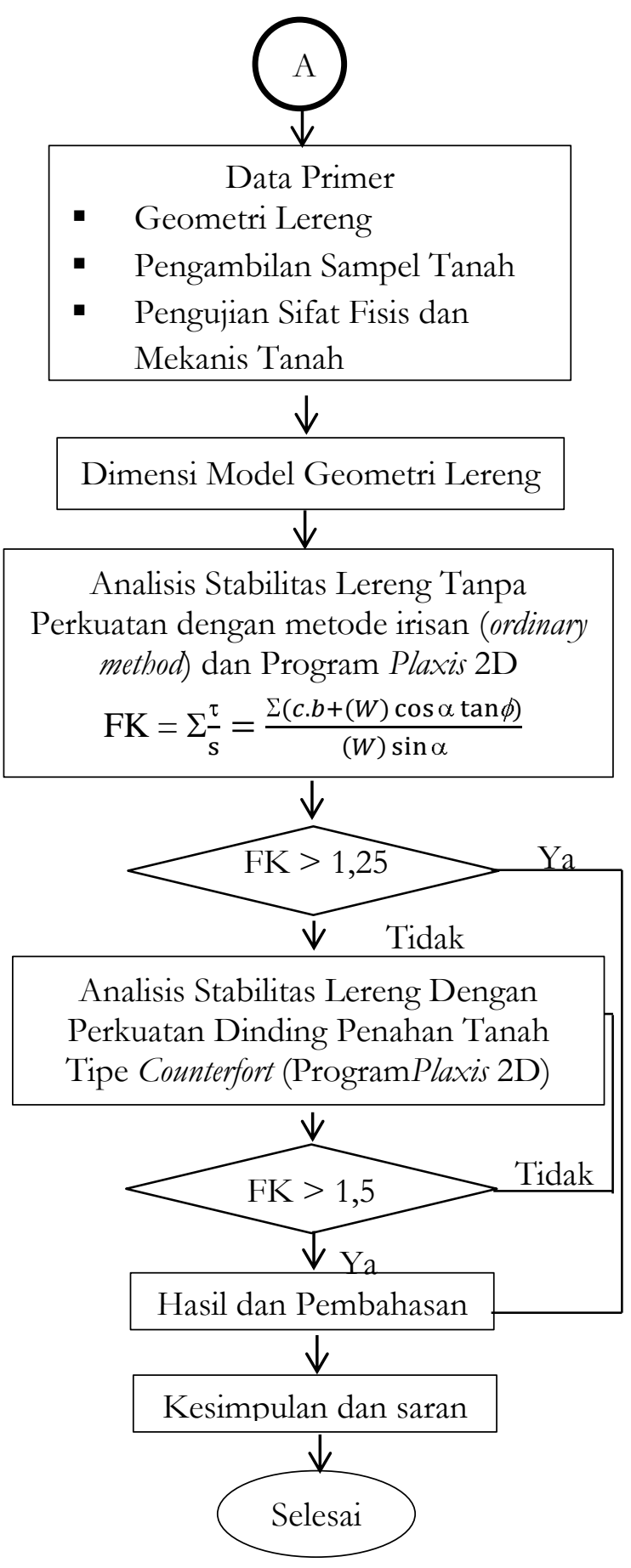

Gambar 2 : Bagan Alir Penelitian

\section{HASIL DAN PEMBAHASAN}

Dalam bab ini didapatkan hasil analisa stabilitas lereng pada kondisi eksisting (natural condution) menggunakan metode irisan (ordinary method) dan program Plaxis 2D serta analisa stabilitas lereng setelah diperkuat dengan dinding penahan tanah 
tipe Counterfort hanya menggunakan program saja.

\subsection{Hasil analisis stabilitas lereng menggunakan Metode Irisan}

(Ordinary Method) dan Program

\section{Plaxis 2D}

Analisis stabilitas lereng pada kondisi eksisting dengan menggunakan metode irisan (ordinary method) dan program Plaxis 2D untuk mendapatkan angka faktor keamanan (safety factor). Perhitungan dengan metode irisan (ordinary method) dilakukan berdasarkan bidang longsor (slip surface) pada program Plaxis 2D. Hasil analisis stabilitas lereng pada kondisi eksisting menggunakan program Plaxis 2D dengan beban kendaraan yaitu sebesar $15 \mathrm{kN} / \mathrm{m}^{2}$, seperti diperlihatkan pada Gambar 3 dan 4. Persyaratan aman yang diizinkan $>1,25$.

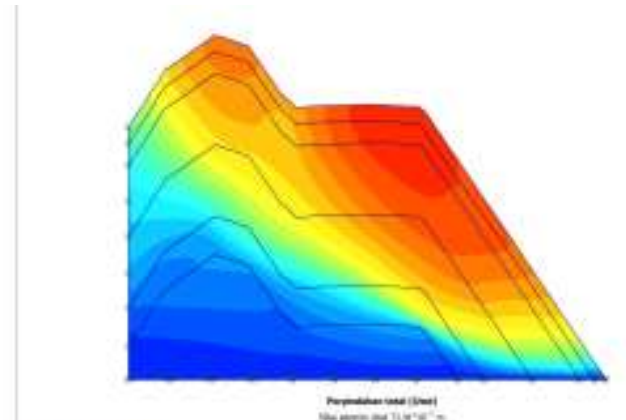

PIAXIS

Gambar 3 : Perpindahan Total (Total Displacement)

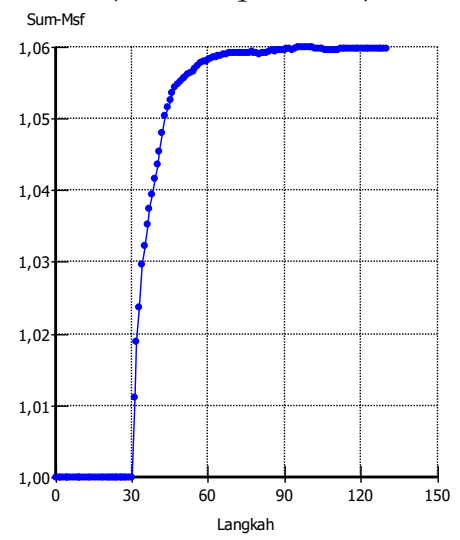

Gambar 4 : Faktor Keamanan Pada Program Plaxis 2D
Hasil analisis stabilitas lereng pada kondisi eksisting dengan menggunakan program Plaxis 2D, menunjukan bahwa faktor keamanan (safety factor) pada $\mathrm{Km}$ 438+775 yaitu sebesar 1,038 dengan kondisi lereng tidak aman (SF < 1,25).

Hasil analisis stabilitas lereng pada kondisi eksisting dengan menggunakan metode irisan (ordinary method), dalam memudahkan perhitungan untuk mendapatkan faktor keamanan (safety factor), maka dilakukan dengan cara membagikan bidang longsor (slip surface) kedalam beberapa irisan.

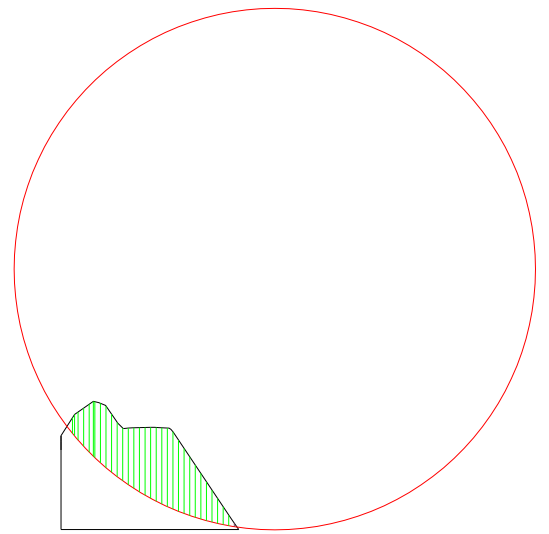

Gambar 5 : Bidang Keruntuhan Lereng

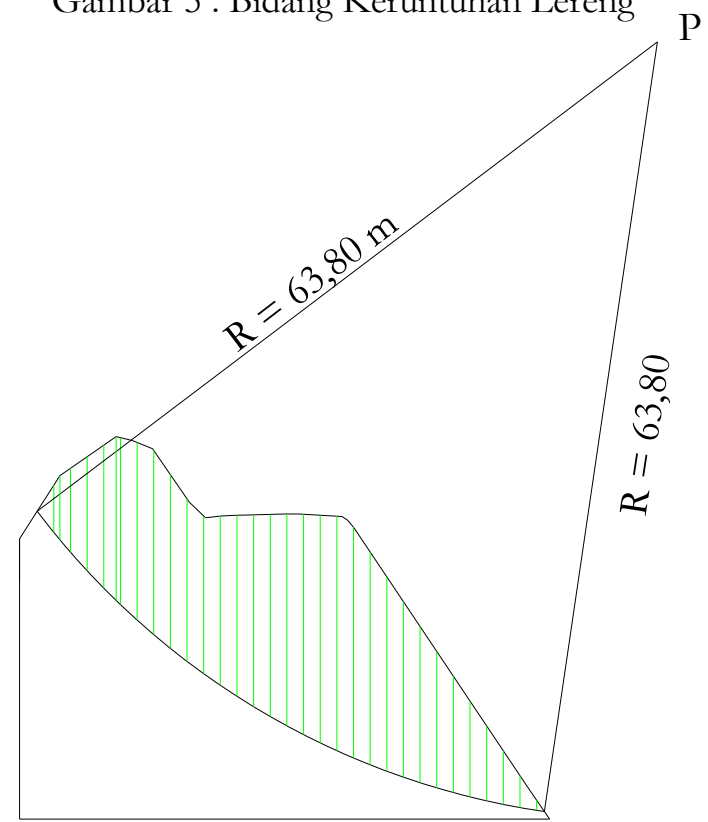

Gambar 6 : Jari-Jari Lingkaran Bidang Keruntuhan Lereng 


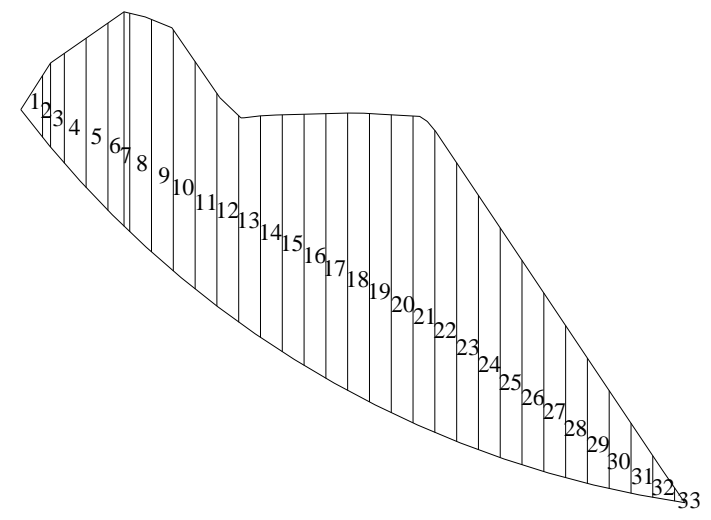

Gambar 7 : Pembagian Bidang Keruntuhan Lereng Ke Beberapa Irisan

Hasil analisis stabilitas lereng pada kondisi eksisting dengan menggunakan metode irisan (ordinary method), menunjukan bahwa faktor keamanan (safety factor) pada Km 438+775 dengan jari-jari bidang 63,80 $m$ didapatkan faktor keamanan sebesar 1,079 dengan kondisi lereng tidak aman (SF $<1,25)$.

Tabel 2 : Parameter Tanah dan Perhitungan Luas Irisan serta Berat Irisan pada $\mathrm{Km} \mathrm{438+775}$

\begin{tabular}{|c|c|c|c|c|c|c|c|c|}
\hline \multirow{3}{*}{$\begin{array}{c}\text { No } \\
\text { Irisan }\end{array}$} & \multicolumn{3}{|c|}{ Variabel (m) } & \multirow{2}{*}{\begin{tabular}{|c|}
$\begin{array}{c}\text { Luas Irisan } \\
\left(\mathrm{m}^{2}\right)\end{array}$ \\
\end{tabular}} & \multirow{2}{*}{$\begin{array}{r}\gamma \text { tanah } \\
\left(\mathrm{kN} / \mathrm{m}^{3}\right) \\
\end{array}$} & \multirow{2}{*}{\begin{tabular}{|c|} 
Kohesi (c) \\
$\left(\mathrm{kN} / \mathrm{m}^{2}\right)$ \\
\end{tabular}} & \multirow{2}{*}{$\varphi\left({ }^{\theta}\right)$} & \multirow{2}{*}{$\begin{array}{l}\text { Berat Per Irisan } \\
\text { (W) }(\mathrm{kN} / \mathrm{m})\end{array}$} \\
\hline & hl & h2 & $\mathrm{L}$ & & & & & \\
\hline & 1 & 2 & 3 & 4 & 5 & 6 & 7 & $9=4 \times 5$ \\
\hline 1 & 0,00 & 3,88 & 2,19 & 4,249 & \multirow{33}{*}{20,928} & \multirow{33}{*}{33,648} & \multirow{33}{*}{25,7} & 88,915 \\
\hline 2 & 3,88 & 5,27 & 0,81 & 3,706 & & & & 77,554 \\
\hline 3 & 5,27 & 6,89 & 1,32 & 8,026 & & & & 167,960 \\
\hline 4 & 6,89 & 9,36 & 2,12 & 17,225 & & & & 360,485 \\
\hline 5 & 9,36 & 11,74 & 1,98 & 20,889 & & & & 437,165 \\
\hline 6 & 11,74 & 13,44 & 1,42 & 17,878 & & & & 374,147 \\
\hline 7 & 13,44 & 13,70 & 0,50 & 6,785 & & & & 141,996 \\
\hline 8 & 13,70 & 14,57 & 1,86 & 26,291 & & & & 550,220 \\
\hline 9 & 14,57 & 15,11 & 1,81 & 26,860 & & & & 562,134 \\
\hline 10 & 15,11 & 14,19 & 1,82 & 26,663 & & & & 558,003 \\
\hline 11 & 14,19 & 13,33 & 1,71 & 23,530 & & & & 492,427 \\
\hline 12 & 13,33 & 12,94 & 1,70 & 22,330 & & & & 467,312 \\
\hline 13 & 12,94 & 13,88 & 1,68 & 22,529 & & & & 471,483 \\
\hline 14 & 13,88 & 14,85 & 1,60 & 22,984 & & & & 481,009 \\
\hline 15 & 14,85 & 15,74 & 1,64 & 25,084 & & & & 524,954 \\
\hline 16 & 15,74 & 16,58 & 1,59 & 25,694 & & & & 537,732 \\
\hline 17 & 16,58 & 17,38 & 1,56 & 26,489 & & & & 554,358 \\
\hline 18 & 17,38 & 18,07 & 1,55 & 27,474 & & & & 574,971 \\
\hline 19 & 18,07 & 18,67 & 1,52 & 27,922 & & & & 584,360 \\
\hline 20 & 18,67 & 19,23 & 1,51 & 28,615 & & & & 598,844 \\
\hline 21 & 19,23 & 19,93 & 1,49 & 29,174 & & & & 610,558 \\
\hline 22 & 19,93 & 17,46 & 1,48 & 27,669 & & & & 579,048 \\
\hline 23 & 17,46 & 15,95 & 1,46 & 24,389 & & & & 510,419 \\
\hline 24 & 15,95 & 14,40 & 1,46 & 22,156 & & & & 463,670 \\
\hline 25 & 14,40 & 12,81 & 1,44 & 19,591 & & & & 410,005 \\
\hline 26 & 12,81 & 11,19 & 1,43 & 17,160 & & & & 359,124 \\
\hline 27 & 11,19 & 9,54 & 1,42 & 14,718 & & & & 308,025 \\
\hline 28 & 9,54 & 7,86 & 1,41 & 12,267 & & & & 256,724 \\
\hline 29 & 7,86 & 6,14 & 1,40 & 9,800 & & & & 205,094 \\
\hline 30 & 6,14 & 4,39 & 1,40 & 7,371 & & & & 154,260 \\
\hline 31 & 4,39 & 2,61 & 1,39 & 4,865 & & & & 101,815 \\
\hline 32 & 2,61 & 0,83 & 1,38 & 2,374 & & & & 49,675 \\
\hline 33 & 0,83 & 0,00 & 0,65 & 0,270 & & & & 5,645 \\
\hline$\Sigma$ & & & 49,70 & & & & & \\
\hline
\end{tabular}

Perhitungan Irisan Ke-1

W

$$
\begin{aligned}
& =\gamma \times \text { Luas Irisan } 1 \\
& =20,928 \mathrm{kN} / \mathrm{m}^{3} \times 4,249 \mathrm{~m}^{2} \\
& =88,915 \mathrm{kN} / \mathrm{m}
\end{aligned}
$$

\begin{tabular}{|c|c|c|c|c|c|c|c|c|}
\hline No & Berat Per Irisan & Sudut $\alpha$ & $\alpha$ (rad) & $\sin \alpha$ & $\cos \alpha$ & $\mathrm{W} \sin \alpha$ & $\mathrm{W} \cos \alpha$ & $\mathrm{SF}$ \\
\hline & \begin{tabular}{|c|c|c|} 
& $=4 \times 5)$ \\
\end{tabular} & 10 & 11 & 12 & 13 & $14=9 \times 12$ & $14=9 \times 13$ & 15 \\
\hline 1 & 88,915 & 52 & 0,907 & 0,788 & 0,616 & 70,028 & 54,790 & \multirow{33}{*}{1,079} \\
\hline 2 & 77,554 & 51 & 0,889 & 0,777 & 0,630 & 60,238 & 48,847 & \\
\hline 3 & 167,960 & 50 & 0,872 & 0,766 & 0,643 & 128,593 & 108,048 & \\
\hline 4 & 360,485 & 48 & 0,837 & 0,743 & 0,670 & 267,738 & 241,382 & \\
\hline 5 & 437,165 & 46 & 0,802 & 0,719 & 0,695 & 314,284 & 303,873 & \\
\hline 6 & 374,147 & 45 & 0,785 & 0,707 & 0,708 & 264,403 & 264,720 & \\
\hline 7 & 141,996 & 45 & 0,785 & 0,707 & 0,708 & 100,347 & 100,467 & \\
\hline 8 & 550,220 & 43 & 0,750 & 0,682 & 0,732 & 375,019 & 402,620 & \\
\hline 9 & 562,134 & 41 & 0,715 & 0,656 & 0,755 & 368,562 & \begin{tabular}{|l|}
424,449 \\
\end{tabular} & \\
\hline 10 & 558,003 & 40 & 0,698 & 0,642 & 0,766 & 358,450 & 427,646 & \\
\hline 11 & 492,427 & 38 & 0,663 & 0,615 & 0,788 & 302,973 & 388,191 & \\
\hline 12 & 467,312 & 36 & 0,628 & 0,587 & 0,809 & 274,498 & 378,195 & \\
\hline 13 & 471,483 & 35 & 0,610 & 0,573 & 0,819 & 270,252 & 386,342 & \\
\hline 14 & 481,009 & 33 & 0,576 & 0,544 & 0,839 & 261,799 & 403,523 & \\
\hline 15 & 524,954 & 32 & 0,558 & 0,530 & 0,848 & 277,994 & 445,304 & \\
\hline 16 & 537,732 & 31 & 0,541 & 0,515 & 0,857 & 276,763 & \begin{tabular}{|l|}
461,041 \\
\end{tabular} & \\
\hline 17 & 554,358 & 29 & 0,506 & 0,484 & 0,875 & 268,571 & 484,956 & \\
\hline 18 & 574,971 & 28 & 0,488 & 0,469 & 0,883 & 269,743 & 507,769 & \\
\hline 19 & 584,360 & 26 & 0,453 & 0,438 & 0,899 & 255,985 & 525,308 & \\
\hline 20 & 598,844 & 25 & 0,436 & 0,422 & 0,906 & 252,902 & 542,821 & \\
\hline \begin{tabular}{|l|}
21 \\
\end{tabular} & 610,558 & 24 & 0,419 & 0,406 & 0,914 & 248,158 & 557,851 & \\
\hline 22 & 579,048 & 22 & 0,384 & 0,374 & 0,927 & 216,758 & \begin{tabular}{|l|}
536,948 \\
\end{tabular} & \\
\hline \begin{tabular}{|l|}
23 \\
\end{tabular} & 510,419 & 21 & 0,366 & 0,358 & 0,934 & 182,785 & 476,568 & \\
\hline 24 & 463,670 & 20 & 0,349 & 0,342 & 0,940 & 158,469 & 435,750 & \\
\hline \begin{tabular}{|l|}
25 \\
\end{tabular} & 410,005 & 18 & 0,314 & 0,309 & 0,951 & 126,605 & 389,968 & \\
\hline \begin{tabular}{|l|}
26 \\
\end{tabular} & 359,124 & 17 & 0,296 & 0,292 & 0,956 & 104,920 & 343,456 & \\
\hline \begin{tabular}{|l|}
27 \\
\end{tabular} & 308,025 & 16 & 0,279 & 0,275 & 0,961 & 84,840 & 296,110 & \\
\hline \begin{tabular}{|l|}
28 \\
\end{tabular} & 256,724 & 15 & 0,262 & 0,259 & 0,966 & 66,396 & 247,989 & \\
\hline \begin{tabular}{|l|}
29 \\
\end{tabular} & 205,094 & 13 & 0,227 & 0,225 & 0,974 & 46,102 & \begin{tabular}{|l|l}
199,846 \\
\end{tabular} & \\
\hline \begin{tabular}{|l|}
30 \\
\end{tabular} & 154,260 & 12 & 0,209 & 0,208 & 0,978 & 32,048 & 150,894 & \\
\hline 31 & 101,815 & 11 & 0,192 & 0,191 & 0,982 & 19,413 & 99,947 & \\
\hline \begin{tabular}{|l|}
32 \\
\end{tabular} & 49,675 & 10 & 0,174 & 0,174 & 0,985 & 8,619 & 48,921 & \\
\hline 33 & 5,645 & 9 & 0,157 & 0,156 & 0,988 & 0,882 & 5,576 & \\
\hline$\Sigma$ & & & & & & 6315,138 & \begin{tabular}{|l|l|}
10690,116 \\
\end{tabular} & \\
\hline
\end{tabular}

Tabel 3 : Perhitungan Faktor Keamanan (Safety Factor)

Perhitungan Untuk SF $=1,079$

$F K=\frac{\sum\left(c^{\prime} l+W t \cos \alpha \tan \varphi^{\prime}\right)}{\Sigma W t \sin \alpha}$

$F K=\frac{\Sigma(33,648 \times 49,70)+(10690,116(\tan (25,7) \times 0,01744))}{6315,138}$

$\mathrm{FK}=1,079$

Jadi, didapatkan faktor keamanan (safety factor) dari lereng tersebut adalah $\mathrm{SF}=1,079$

\subsection{Hasil Analisis Stabilitas Lereng Setelah Diperkuat Dinding Penahan Tanah Tipe Counterfort Menggunakan Program Plaxis 2D}

Hasil analisis stabilitas lereng setelah diperkuat dinding penahan tanah tipe counterfort menggunakan program Plaxis dengan beban kendaraan yaitu sebesar 15 
$\mathrm{kN} / \mathrm{m}^{2}$. Perhitungan faktor keamanan (safety) factor) setelah diperkuat dinding penahan tanah tipe counterfort seperti diperlihatkan pada Gambar 8 dan 9. Persyaratan aman yang diizinkan $\mathrm{SF}>1,50$.

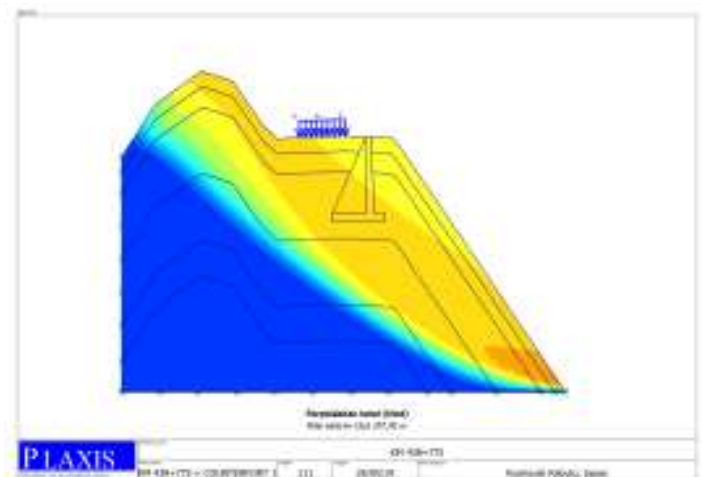

Gambar 8 : Perpindahan Total (Total Displacement)

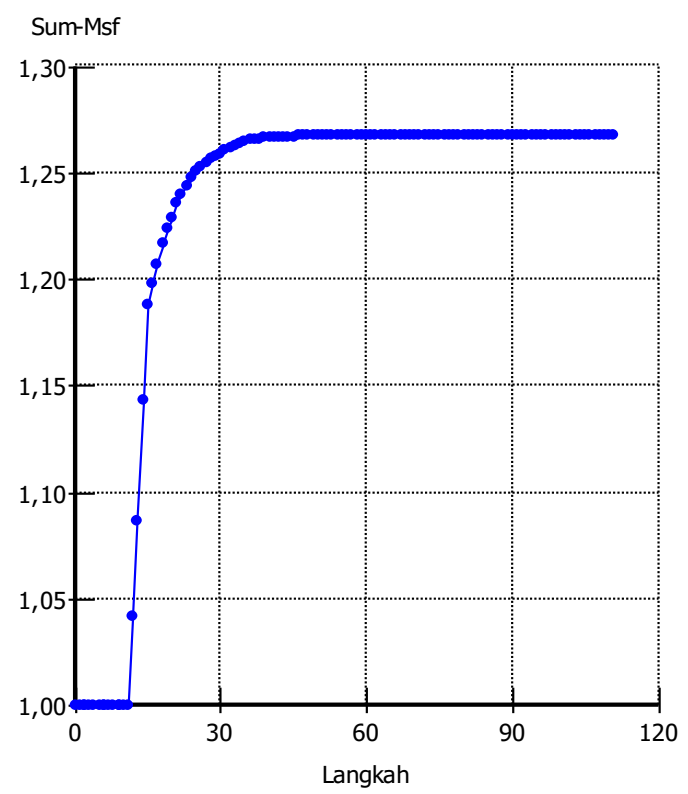

Gambar 9 : Faktor Keamanan Pada Program Plaxis 2D

Hasil analisis stabilitas lereng setelah diperkuat dinding penahan tanah tipe counterfort dengan menggunakan program Plaxis, menunjukan bahwa faktor keamanan

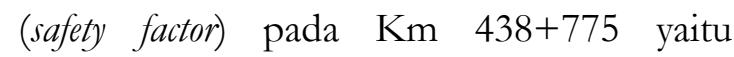
sebesar 1,268 dengan kondisi lereng tidak $\operatorname{aman}(\mathrm{SF}<1,50)$.
Hasil analisis stabilitas lereng setelah diperkuat dinding penahan tanah tipe counterfort dan minipile menggunakan program Plaxis dengan beban kendaraan yaitu sebesar $15 \mathrm{kN} / \mathrm{m}^{2}$. Perhitungan faktor keamanan (safety factor) setelah diperkuat dinding penahan tanah tipe counterfort dan minipile, seperti diperlihatkan pada Gambar 10 dan 11. Persyaratan aman yang diizinkan $\mathrm{SF}>1,50$.

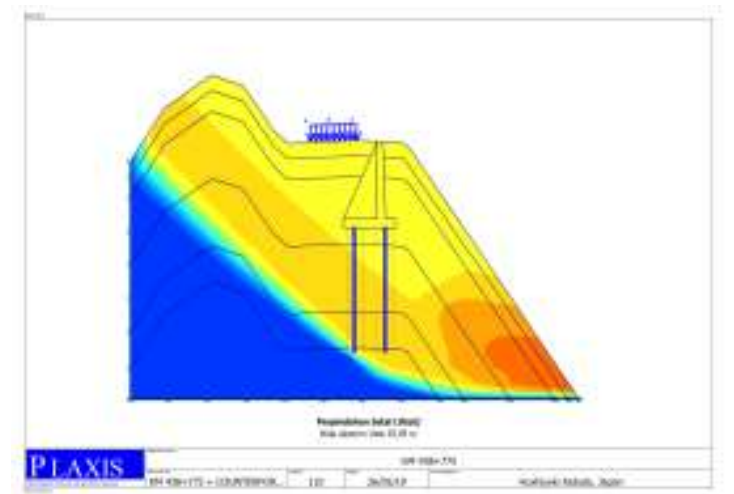

Gambar $10: \begin{gathered}\text { Perpindahan Total (Total } \\ \text { Displacement) }\end{gathered}$

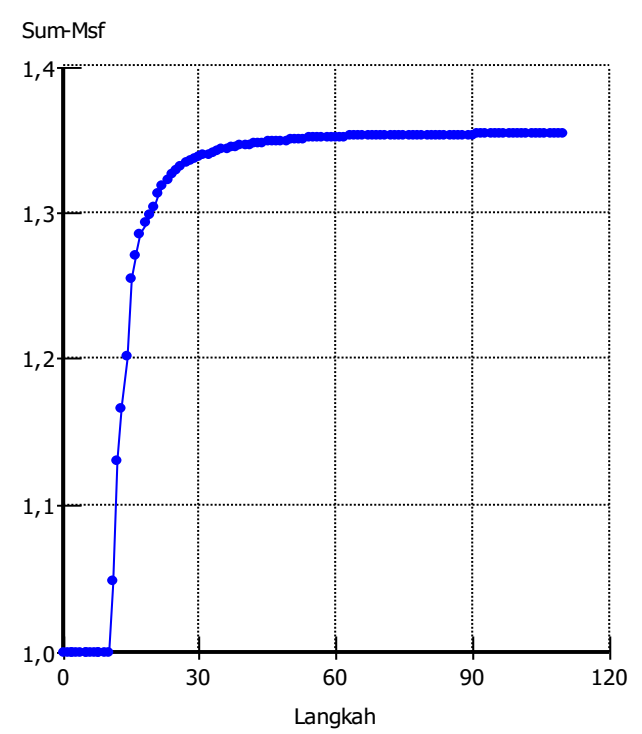

Gambar 11 : Faktor Keamanan Pada Program Plaxis 2D

Hasil analisis stabilitas lereng setelah diperkuat dinding penahan tanah tipe counterfort dan minipile dengan panjang 12 meter menggunakan program Plaxis, menunjukan bahwa faktor keamanan pada 
Km 438+775 sebesar 1,354 dengan kondisi lereng tidak aman $(\mathrm{SF}<1,50)$.

Hasil analisis stabilitas lereng setelah diperkuat dinding penahan tanah tipe counterfort, minipile dan angkur menggunakan program Plaxis dengan beban kendaraan yaitu sebesar $15 \mathrm{kN} / \mathrm{m}^{2}$. Perhitungan faktor keamanan (safety factor) setelah diperkuat dinding penahan tanah tipe counterfort, minipile dan angkur, seperti diperlihatkan pada Gambar 12 dan 13. Persyaratan aman yang diizinkan $\mathrm{SF}>1,50$.

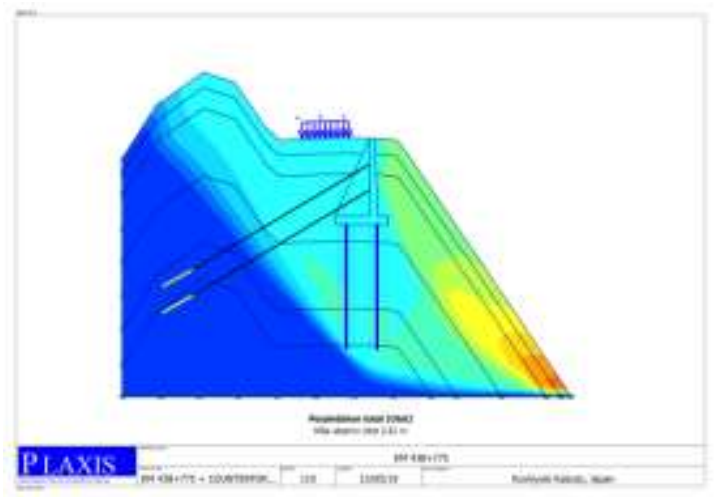

Gambar 12 : Perpindahan Total (Total Displacement)

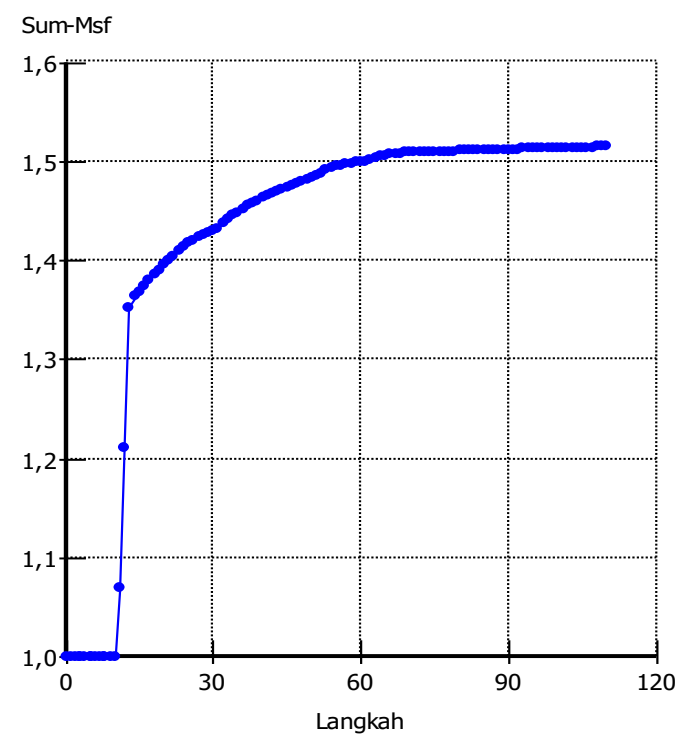

Gambar 13 : Faktor Keamanan Pada Program Plaxis 2D

Hasil analisis stabilitas lereng setelah diperkuat dinding penahan tanah tipe counterfort, minipile dengan panjang 12 meter dan angkur dengan panjang 20 meter serta sudut kemiringan $30^{\circ}$ menggunakan program Plaxis, menunjukan bahwa faktor keamanan (safety factor) pada Km 438+775 yaitu sebesar 1,513 dengan kondisi lereng $\operatorname{aman}(\mathrm{SF}>1,50)$.

\subsection{Pembahasan}

Hasil analisis stabilitas lereng pada kondisi eksisting (natural condition) menggunakan data seperti pada Tabel 1 di $\mathrm{Km} \quad 438+775$ dengan menggunakan program Plaxis 2D, didapatkan nilai faktor keamanan (safety factor) lebih kecil dari 1,25 dalam kondisi tidak aman $(\mathrm{SF}<1,25)$. Sedangkan perhitungan dengan menggunakan metode irisan (ordinary method) $\mathrm{Km} \quad 438+775$ dengan jari-jari 63,80 m didapatkan nilai faktor keamanan (safety factor) lebih kecil dari 1,25 dalam kondisi tidak aman $(\mathrm{SF}<1,25)$. Dengan demikian, maka perlu dilakukan perkuatan lereng dengan menggunakan dinding penahan tanah tipe Counterfort.

Gambar 14 Menunjukkan bahwa hasil analisis stabilitas lereng setelah diperkuat dinding penahan tanah tipe Counterfort pada $\mathrm{Km}$ 438+775, menunjukkan bahwa nilai faktor keamanan (safety factor) lebih kecil dari 1,50 dalam kondisi lereng tidak aman (SF < 1,50). Hal ini disebabkan, perkuatan pada lereng tidak melewati bidang gelincir (slip surface), sehingga diperlukan perkuatan tambahan dengan menambahkan minipile.

Hasil analisis stabilitas lereng setelah diperkuat dinding penahan tanah tipe Counterfort dan minipile sepanjang 12 meter pada Km 438+775 didapatkan nilai faktor keamanan (safety factor) lebih kecil dari 1,50 dalam kondisi lereng tidak aman (SF < 1,50). Berdasarkan hasil analisis didapatkan nilai faktor keamanan (safety factor) 
meningkat setelah dilakukan perkuatan tambahan. Sehingga, diperlukan perkuatan tambahan untuk meningkatkan faktor keamanan (safety factor), dengan dilakukan pemasangan anchor pada dinding panahan tanah tipe Counterfort. Hasil analisis stabilitas lereng setelah diperkuat dinding penahan tanah tipe counterfort, minipile dan anchor pada Km 438+775 dengan panjang 20 meter serta sudut kemiringan $30^{\circ}$, didapatkan angka faktor keamanan 1,513 dengan kondisi lereng aman (SF > 1,50).

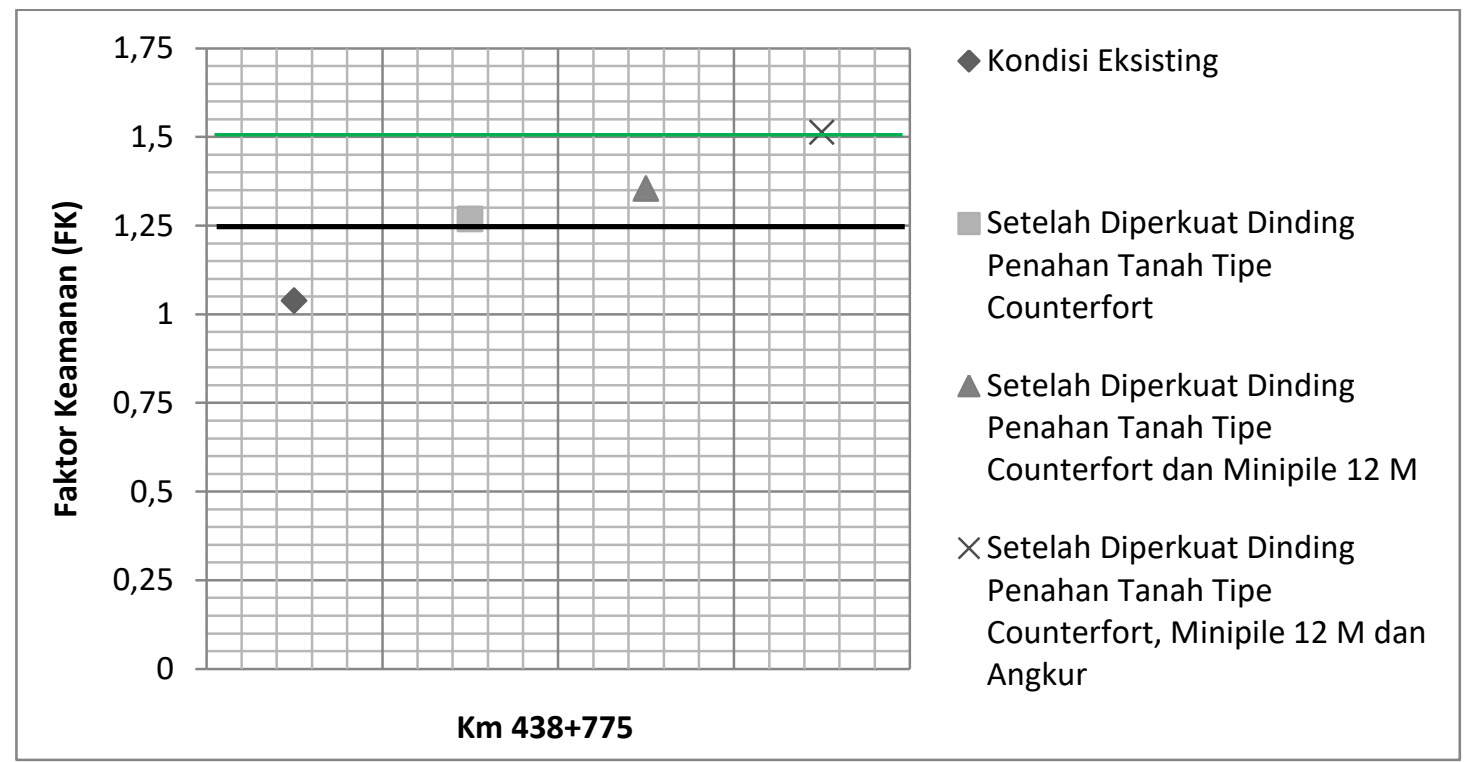

Gambar 14 : Grafik Perhitungan Faktor Keamanan (Safety Factor) pada Kondisi Eksisting dan Setelah Dilakukan Perkuatan Lereng

Keterangan :

$$
\begin{aligned}
& =\text { Batas Faktor Keamanan yang diizinkan Untuk Kondisi Eksisting }(\mathrm{SF}>1,25) . \\
& =\text { Batas Faktor Keamanan yang diizinkan Setelah Diberi Perkuatan }(\mathrm{SF}>1,50) .
\end{aligned}
$$

\section{KESIMPULAN}

Berdasarkan hasil dan pembahasan tentang analisis kestabilan lereng dengan cara perhitungan metode irisan dan menggunakan program Plaxis 2D dapat diambil kesimpulan sebagai berikut:

1. Faktor Keamanan pada kondisi existing (natural condition) dengan Program Plaxis 2D dan metode irisan pada Km $438+775$ adalah sebesar 1,038 dengan kondisi lereng tidak aman $(\mathrm{SF}<1,25)$

2. Faktor Kemanan setelah diperkuat dinding penahan tanah tipe Counterfort dengan Program Plaxis 2D pada Km 438+775 adalah sebesar 1,268 dengan kondisi lereng tidak aman $(\mathrm{SF}<1,50)$.
Dengan demikian, diperkuatan tambahan untuk meningkatkan faktor keamanan (FK).

3. Faktor Kemanan setelah diperkuat dinding penahan tanah tipe Counterfort dan minipile dengan panjang 12 meter dengan Program Plaxis 2D pada Km $438+775$ adalah sebesar 1,354 dengan kondisi lereng tidak aman $(\mathrm{SF}<1,50)$

4. Faktor Kemanan setelah diperkuat dinding penahan tanah tipe Counterfort, minipile dengan panjang 12 meter dan angkur dengan panjang 20 meter serta sudut kemiringan $30^{\circ}$ dengan Program Plaxis 2D pada $\mathrm{Km} 438+775$ adalah sebesar 1,513 dengan kondisi lereng aman $(\mathrm{SF}>1,50)$ 


\section{DAFTAR PUSTAKA}

[1] Yulvi, Z., Pengarub Beban Dinamis dan Kadar Air Tanah Terbadap Stabilitas Lereng pada Tanah Lempung Berpasir, Jurnal Rekayasa Sipil Vol 5.

[2] Hardiyatmo, H. C, 1994. Mekanika Tanah 1, PT. Gramedia Pustaka Utama, Jakarta.

[3] Bowles, J. E, 1993. Sifat-sifat Fisis dan Geoteknis Tanah, terjemahan J.K. Hainim, Edisi Kedua, Penerbit Erlangga, Jakarta.

[4] Duncan, J.M., 2005. Soil Strength and Slope Stability, John Willey \& Son INC. New York.

[5] Abramson, L. W. et al, Slope Stability and Stabilization Methods, Wiley and Sons Inc, New York, 1996.

[6] Bowles, J. E, 1993. Sifat-sifat Fisis dan Geoteknis Tanah, terjemahan J.K. Hainim, Edisi Kedua, Penerbit Erlangga, Jakarta.

[7] Hasyim, A, Slope Stability Analysis in Saturated Slope, Faculty of Civil Engineering Universiti Teknologi Malaysia, inside.mines.edu, Malaysia, 2007.

[8] Rinanditya, F, R, Analisis Stabilitas Lereng Dengan Dinding Penahan Tanah Kantilever Menggunakan Program Plaxis (Studi Kasus Jalan Piyungan-Batas Gunung Kidul, Yogyakarta. Jurnal. Tidak di Terbitkan. Program Studi Teknik Sipil. Universitas Muhammadiyah Surakarta, 2017.

[9] Abiyyu, M. F, Perencanaan Perkuatan Lereng Menggunakan Dinding Penahan Tanab Tipe Kantilever Di Tol Jakarta Outer Ring Road II, Dapartemen Teknik Sipil dan Lingkungan, Institut Pertanian Bogor, 2018.

[10] Das, B. M, 1993. Mekanika Tanah Jilid 2, Penerbit Erlangga, Jakarta. 